\title{
Smart concept in rural tourism: a comparison between two phases (2016-2019)
}

\author{
Conceito inteligente em turismo rural: uma comparação entre dois \\ períodos (2016-2019)
}

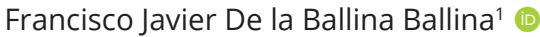

${ }^{1}$ Facultad de Economía y Empresa, Proyecto SITA, Universidad de Oviedo (UNIOVI), Oviedo (Asturias), España. E-mail: fballina@uniovi.es

How to cite: Ballina, F. J. D. B. (2022). Smart concept in rural tourism: a comparison between two phases (2016-2019).

Revista de Economia e Sociologia Rural, 60(1), e234629. https://doi.org/10.1590/1806-9479.2021.234629

\begin{abstract}
Smart Tourism is the main component of current destinations, however, there are severe difficulties for its application in small destinations. This problem is essential in the case of rural tourism. Taramundi is one of the most important rural destinations in Spain. There are two surveys about tourists conducted in 2016 and 2019. These surveys are about obtaining data on changes in the behavior of tourists in the dynamic field of mobile technologies. The results indicated the importance of the smartphone for rural tourism, the temporary growth in the use of its tourist utilities, and most importantly, the technological applications that improve the enjoyment stay. The rural tourist does not abandon the use of pre- and posttravel regarding Information and Communication Technologies (ICTS), but the interest in Tics during travel increases significantly. Specifically, the App of Destiny is the central element of smart rural tourism, seeing that it should focus on the increase of new technographic utilities for tourists. In the perspective of Gretzel (2018), the application of the concept of Smart Tourist Destination is impossible in rural areas. However, with a specialization approach, rural destinations must work towards the goal of "smartification."
\end{abstract}

Keywords: rural tourism, destinations, ICTS, Smart, App.

Resumo: O Turismo Inteligente é o principal componente dos destinos atuais, mas existem sérias dificuldades para sua aplicação em pequenos destinos, sobretudo no caso do turismo rural. Taramundi é um dos destinos rurais mais importantes da Espanha. Existem dois inquéritos sobre turistas realizados nessa localidade em 2016 e 2019. Esta pesquisa visa obter dados sobre as mudanças no comportamento dos turistas no domínio dinâmico das tecnologias móveis. Os resultados indicam a importância do smartphone para o turismo rural, o crescimento temporário da utilização dos seus utilitários turísticos e, principalmente, as aplicações tecnológicas, que melhoram a fruição da estadia. O turista rural não abandona o uso das tecnologias da informação e comunicação (TICS) pré e pós-viagem, mas o interesse pelas TICs durante a viagem aumenta significativamente. Especificamente, o App of Destiny é o elemento central do turismo rural inteligente, pois ele deve se concentrar no aumento de novas utilidades tecnológicas para os turistas. Na perspectiva de Gretzel (2018), a aplicação do conceito de Destino Turístico Inteligente é impossível no meio rural. No entanto, com uma abordagem de especialização, os destinos rurais devem trabalhar objetivando a "smartification".

Palavras-chave: turismo rural, destinos, TICS, Smart, App.

\section{INTRODUCTION}

Smart Tourism is a concept derived directly from the Smart City literature (Mora et al., 2017). There are several reasons to follow the urban destination approach: business concentration; and infrastructure. Regarding this "urban" burden, this concept will take a complicated approach to apply the concept of Smart Tourism to other types of destinations (Gretzel, 2018).

Yigitcanlar et al. (2018) suggested three dimensions in Smart Tourism as following: technological; human; and institutional. The technological dimension establishes links with the physical infrastructure, and also provides the fundamentals for tourist front-end solutions, i.e., an experience enriched with technologies and data (Gretzel et al., 2018). 
The Smart Tourism is mostly applied in the destination ambit (Gretzel, 2018), and Koo et al. (2016) pointed out to Information and Communication Technologies (ICTs) as a fundamental pillar for competition; nevertheless, Jovicic (2017) highlighted how, without the use of ICTs, destinations are unable to achieve a substantial value for their geographical attributes in the tourist market; and Femenia et al. (2018) indicated that destinations use ICTs primarily to change the tourist's relationship with the destination itself.

In spite of ICTS has not been considered in the field of rural tourism, Wilson et al. (2001) proposed up to 10 conditions for the development of RT and did not include ICTs; Zdorov (2004) made his proposal and did not incorporate ICTs; even more recently, Barbu (2013) proposed seven factors, and no one was associated to ICTs.

However, from the different needs and approaches used in tourism (Saarinen et al., 2017), as well as in the framework of sustainable planning (Moscardo and Murphy, 2014), ICTs play an essential role on all types of tourism (Benckendorff et al., 2014), including rural tourism.

Concretely, the social media technologies have altered the behavior of rural tourists due to prior research about the destination, accommodation, and activities carried out during the trip and even in the way of sharing the experience on their return (Santos et al., 2016; Upkabi \& Karjaluoto, 2017). Therefore, the trend is dictated by the rural entrepreneurs offering new ICTs approaches to add value to the tourist experience (Weindenfeld, 2018). Thus, the ICTs are omnipresent in the vacation demands of tourists because they maximize customization and interaction (Garau, 2015).

The ICTs allow rural areas to achieve visibility, communication, integration into tourist flows, marketing of products, and services of higher quality (Sedmak et al., 2016). Rural tourism consumers are very aspirational, in the sense that they are very proactive to search for information and places with respect to rural destinations (Rodrigues \& Ventura, 2019). Consequently, the concept of Smart Tourism must exceed the urban limits to reach all tourist spaces.

McCann \& Ortega (2013) were the first authors who indicated that regions must develop a smart specialization. Boschma (2014) also analyzed the competing of smart specialization, with emphasis on specific sectors. Smart specialization involves working on the development of innovative ideas in a specific area, which allows generating knowledge about the future value of one direction of change (Weindenfeld, 2018).

In the spirit of smart specialization, the Smart Village Initiative was launched by the European Union (EU) in 2017. The basics of Smart Village are identical to those of Smart City as following: the use of traditional and new networks through digital, innovation technologies; innovations; and better use of knowledge (Zavratnik et al., 2018). The main difference is that, during the initial stages, these are specialized smart projects. The only way to take advantage of rural tourism is the development of Smart Village Tourism, as a mix of traditional rural culture and the utilities of ICTs (Shen \& Wang, 2018). The objective will be focused on balancing competitiveness with social and environmental sustainability (Perles-Ribes et al., 2017; Luque et al., 2015).

There are several initiatives in the world to promote the concept of Smart Village: the first based on education and health objectives; and others in Agriculture, using digital connectivity. However, more recently, it could be noted that there are public projects related to sustainability and then, tourism is being developed (see Figure 1).

There is very little research on smart rural tourism and even less empirical evidence on this subject (Yan, 2018). The development of technological infrastructure has the focus on the majority of papers. There are many small organizations that participate in Rural Tourism i.e., it is reasonable to assume a low capacity to adapt ICTs (Zavratnik et al., 2018). The high ICT volatility and its ever-changing nature, adds difficulties of adaptation in rural tourism (Nkosana et al., 2016). Moreover, recently, the need to study deficiencies of rural smart tourism mobile is increasing (Yan, 2018). 

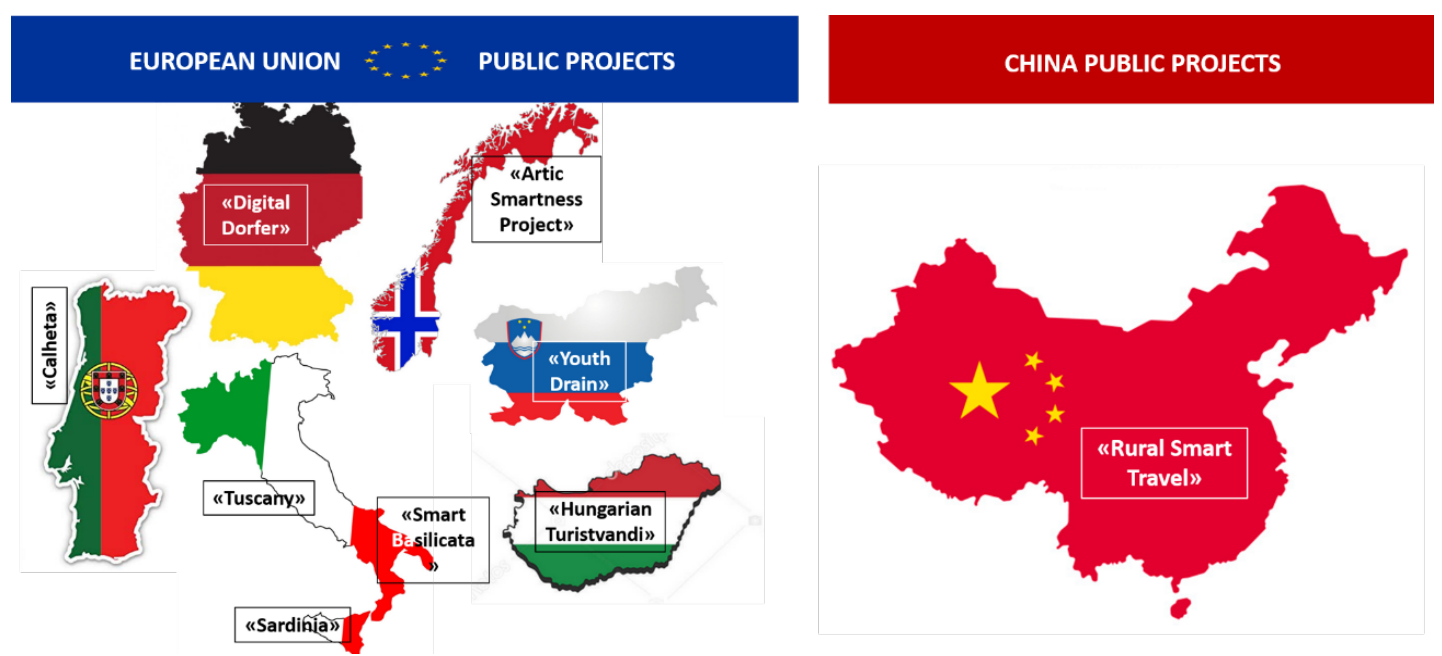

Figure 1: Projects of Smart Village in Sustainability and Tourism.

Sedmark's work (2016) highlighted the critical issue, i.e., the adoption of ICTs in rural tourism. In this work, it could be possible to explore how rural managers perceive the influence of ICTs in their micro-enterprises. Thus, three variables were used in this work as following: ICTs Skills; Benefits (saving time and money); and Market Analysis in a Linear Regression that finds how adoption depends significantly on the Benefits ( 1.162 coefficient), and the Skills (0.692 coefficient).

This paper had a different and complementary approach to this study. The use, knowledge, and interest of ICTs in rural tourist demand were the focus of attention. The behavior of rural tourists is central: their tourist behaviors include their daily technological behaviors (Cunha et al., 2018).

Not all types of tourists, or all types of experiences, or all types of destinations involve the same technological activity by the tourist. Furthermore, this will be changing for the same individual who will use and demand specific technological applications on different trips, or even at different times of the same trip. The technological usability must be analyzed according to the rural tourism experience. It is very important to determine the elements, attributes and / or services of ICTs that are critical for rural tourists. For this purpose, and especially in order to make exciting contributions to the management of the destinations, this paper aimed to study the results obtained at two different time points about the ICTs that were used in the same rural destination, Taramundi. Taramundi is considered the beginning of rural tourism in Spain and a reference model in the study regarding the literature (Valdés \& Del Valle, 2003).

The comparison of the use and interest in ICTs between two different moments in time may prove to be a useful method to study whether the process of the digitalization of citizens is moving towards rural tourism or not. In addition to this, it allows the observation of the existence of qualitative changes in the types of ICTs to the rural tourists.

\section{METHODOLOGY AND HYPHOTESIS}

The data used was obtained through personal surveys of tourists in the rural area of Taramundi (Spain). First, the data were collected in October 2016, and later, with the same questionnaire, in May 2019. The information referred to data provided by tourists, exclusively holiday-type, and all of them were classified as middle seasons. Table 1 presents the technical characteristics of the fieldwork. 
Table 1: Methodology Table

\section{Population and Sample Unit}

Area

Date of Work

Method of Information Collection

Sampling Procedure

Number of Surveys

Sampling Distribution

\section{Holidays Tourists}

Council of Taramundi (Spain)

- October 2016

- May 2019

Personal survey carried out in tourist establishments

Discretionary spending/ never a couple

$536(258+278)$

Proportional to the number of tourist places in the area (347):

(2016) Occupation Rate $=19.20$; Average Overnights $=2.93$.

$\mathrm{N}=683$ Tourists.

(2019) Occupation Rate $=20.16$; Average Overnights $=2.39$.

$\mathrm{N}=883$ Tourists.

$\mathrm{Z}$ at $5 \%, \mathrm{P}=\mathrm{Q}=0.5$

$+/-4.91 \%$
Sampling Conditions

Sample Error

\section{SCALE}

Likert

(1 to 5)

2) Technologies help me to have a more satisfying experience as a rural tourist.

3) Technologies are a fundamental experience as a rural tourist to rural places.

4) Technologies are a useful tool in my travels to rural places.

5) I trust what other tourists say about portals such as TripAdvisor or Booking about rural destination.

6) I valued positively that rural destiny tries to innovate and use technologies to improve my experience as a rural tourist.

Tourist

7) Has traveled with Smartphone

Nominal

8) Has traveled with Tablet

(Yes/No)

9) Has traveled with Notebook

10) Has traveled with Wearables

11) Has used to find general information about the destination

Likert

12) For reservations activities

(1 to 5$)$

13) Has used to seek opinions or criticisms about specific businesses

14) Has used to seek opinions or criticisms about attractions and specific places

15) Has used to take photos and videos

16) Has used to consult maps or use GPS

17) Has used to share experiences on social networks

18) Has used to talk with family and friends

19) Has used to pay

20) Has used to use apps from the destination

21) Has used to use Guides (Audio, Video...) 
Table 2: Continued...

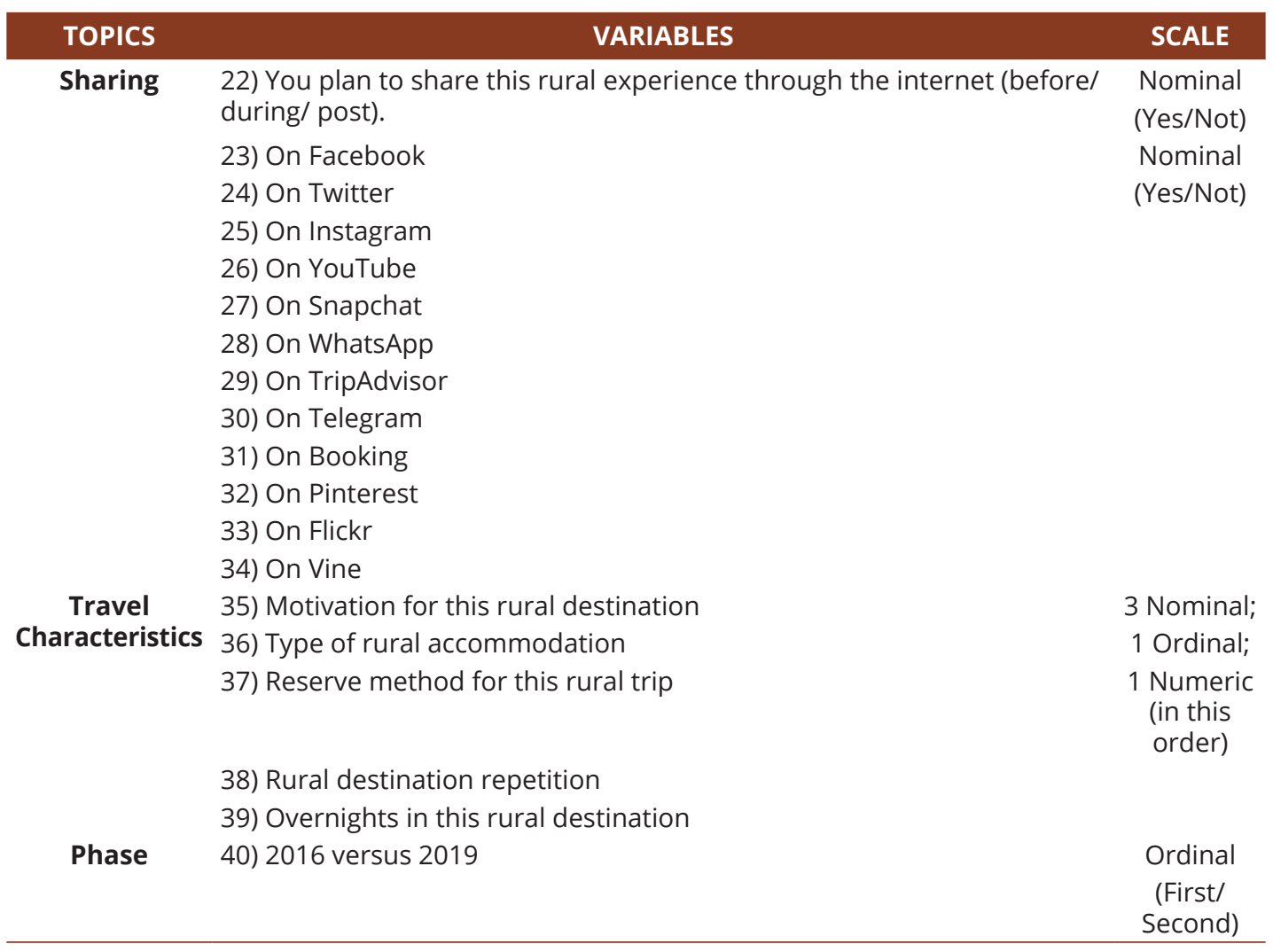

The rural motivations and characteristics, mainly related to the attractiveness of nature, should mean less interest in the use of ICTs for rural tourists. Therefore, technological equipment and applications will not be relevant factors for the assessment and choice of rural destinations (Dolnicar, 2002 and Weinstein, 2011 versus Yan, 2018). Hypothesis 1 is:

- H1: The interest of tourists in rural technological destinations (rural smart tourism) is constantly low.

In any case, the operating characteristics of rural tourism, away from the large distribution channels and operators (Online Travel Agents (OTAs)) and with small and independent accommodation companies, will require tourists to use ICTs related to the information of the destination, and their tourist services (Zavratnik et al., 2018). It is also important to take into account the technological interrelation necessary to make the reservation of accommodation (Hays et al., 2012). Therefore, hypotheses 2 (Bethapudi, 2015; Santos et al., 2016; Upkabi \& Karjaluoto, 2017) is:

- H2: The interest of tourists is high for information associated to ICTs before developing the rural smart tourism trip.

\section{ANALYSIS AND RESULTS}

Prior to the statistical analyses of the database, this work analyzed the profile of the sample. The non-parametric tests were carried out to validate the sample, comprising only a few changes associated to more contracting and booking with Airbnb, HomeAway or Wimdu in phase two. The validity of the scales used had already been verified in 2016, however, the accumulated database of the two phases has been studied with the Cronbach's Alpha test. All the tests performed (see Table 3) could confirm the adequacy of the scales of the variables. 
Table 3: Test of Validity Scales.

\begin{tabular}{lccc}
\multicolumn{2}{c}{ Cronbach's Alpha Test } & $\mathbf{. 7 9 8}$ & Good \\
Tukey's test & Intra elements & $\mathrm{F}=11178.738$ & .000 \\
& Statistical waste & $\mathrm{F}=242.945$ & .000 \\
Hotelling Test & & $\mathrm{F}=1496.418$ & .000 \\
\hline
\end{tabular}

\subsection{ICTs interest in Rural Tourism}

The first question of the model was associated to the study regarding the interest that technologies have for tourists in rural tourism. The works of Ivars et al. (2017), Ivars-Baidal \& Rebollo (2019), Femenia et al. (2018) and Ballina (2019) proposed eight measures of tourist technological interest. This work has selected six of them (see Table 4), which were the most specific works with respect to the interest in rural smart tourism: "I appreciate that rural destiny tries to innovate and use technologies to improve my experience as a rural tourist."

Five of the variables had interest values greater than 3 (midpoint of the scale); the last variable reached a value of 2.87 . The three variables most directly linked to the use of technologies obtained average values greater than 3.5. On the other hand, the variable of interest, which relates destination, technologies, and experience, was closer to 3.5 than the rest (see Table 5).

Interestingly, the five variables on interest in ICTs were significantly correlated with each other (Pearson's coefficient to .000).

The existence of such correlations is essential to accept the validity of the model. A Linear Regression (LR) allows determining the influence on the specific variable (T4: "I appreciate that rural destiny tries to innovate and use technologies to improve my experience as a rural tourist."). Table 5 summarizes the results of LR: R values were higher than .9, even in $R$ quadratic and adjusted above 0.85 . The step LR found two independent variables explaining T4: the first, T2 ("Technologies help me to have a more satisfying experience as tourist.") With a higher beta coefficient (.677); the second, T2 ("Technologies are a fundamental experience as a rural tourist to rural places.") obtained a lower beta coefficient (.311); both with a significance of .000 .

Table 4: Values about ICTs Interest.

\begin{tabular}{lccc} 
& \multicolumn{2}{c}{ Mean } & $\begin{array}{c}\text { Standard } \\
\text { deviation }\end{array}$ \\
\cline { 2 - 3 } & Statistical & $\begin{array}{c}\text { Standard } \\
\text { error }\end{array}$ & .807 \\
$\begin{array}{l}\text { Technologies are a useful tool in my travels to rural } \\
\text { places (T1) }\end{array}$ & 3.73 & .054 & .853 \\
$\begin{array}{l}\text { Technologies are a fundamental experience as a } \\
\text { rural tourist to rural places (T2) }\end{array}$ & 3.69 & .057 & .835 \\
$\begin{array}{l}\text { Technologies help me to have a more satisfying } \\
\text { experience as a rural tourist (T3) }\end{array}$ & 3.57 & .055 & .833 \\
$\begin{array}{l}\text { I appreciate that rural destiny tries to innovate } \\
\text { and use technologies to improve my experience } \\
\text { as a rural tourist (T4) } \\
\text { I trust what other tourists say about portals such } \\
\begin{array}{l}\text { as TripAdvisor or Booking about rural destination } \\
\text { (T5) }\end{array}\end{array}$ & 3.49 & .055 \\
$\begin{array}{l}\text { What I see on social networks influences my } \\
\text { opinion about a rural tourist destination (T6) }\end{array}$ & & & .912 \\
\hline
\end{tabular}


Table 5: Linnear Regression T4 (dependent) / T1, T2, T3, T5 y T6 (independents).

\begin{tabular}{|c|c|c|c|}
\hline Model & $\mathbf{R}$ quadratic & $\begin{array}{l}\text { R quadratic } \\
\text { adjusted }\end{array}$ & \\
\hline 2 & .892 & .891 & \\
\hline & \multirow{2}{*}{ Model } & \multicolumn{2}{|c|}{ Standardized coefficients } \\
\hline & & Beta & Sig. \\
\hline \multirow[t]{2}{*}{2} & $\begin{array}{l}\text { Technologies help me to have a more } \\
\text { satisfying experience as a rural tourist } \\
\text { (T3) }\end{array}$ & .677 & .000 \\
\hline & $\begin{array}{l}\text { Technologies are a fundamental } \\
\text { experience as a rural tourist to rural } \\
\text { places (T2) }\end{array}$ & .311 & .000 \\
\hline
\end{tabular}

The comparison of the values on the interest in ICTs between the two phases could show interesting results. The $t$-Test identified significant differences in five of the six variables used. Only the in T1, Technology as a tool, was lacking explanatory validity (although T1 had the highest value in the first phase and the accumulated study).

All valid variables have been increasing the values from 2019 to 2016 . The increases in variables T3 and T4 stood out for their size, in just over one valuation point ( +1.02 and +1.01 respectively). Likewise, variables T2 and T3 presented values greater than four in2019 (see Table 6).

Table 6: t-Test ICTs Interest and Study Period.

\begin{tabular}{|c|c|c|c|c|}
\hline & $\begin{array}{l}\text { SURVEY } \\
\text { Time }\end{array}$ & Mean & $t$ & $\begin{array}{l}\text { Sig. } \\
\text { (bilateral) }\end{array}$ \\
\hline \multirow{2}{*}{$\begin{array}{l}\text { Technologies help me to have a more } \\
\text { satisfying experience as a rural tourist (T3) }\end{array}$} & Nov2016 & 3.04 & -11.624 & .000 \\
\hline & April2019 & 4.06 & -11.635 & .000 \\
\hline \multirow{2}{*}{$\begin{array}{l}\text { I appreciate that rural destiny tries to } \\
\text { innovate and use technologies to improve } \\
\text { my experience as a rural tourist (T4) }\end{array}$} & Nov2016 & 2.96 & -11.341 & .000 \\
\hline & April2019 & 3.97 & -11.381 & .000 \\
\hline \multirow{2}{*}{$\begin{array}{l}\text { I trust what other tourists say about portals } \\
\text { such as TripAdvisor or Booking about rural } \\
\text { destination (T5) }\end{array}$} & Nov2016 & 2.55 & -9.728 & .000 \\
\hline & April2019 & 3.54 & -9.686 & .000 \\
\hline \multirow{2}{*}{$\begin{array}{l}\text { Technologies are a fundamental experience } \\
\text { as a rural tourist to rural places (T2) }\end{array}$} & Nov2016 & 3.29 & -7.620 & .000 \\
\hline & April2019 & 4.06 & -7.575 & .000 \\
\hline \multirow{2}{*}{$\begin{array}{l}\text { What I see on social networks influences my } \\
\text { opinion about a rural tourist destination (T6) }\end{array}$} & Nov2016 & 2.41 & -4.759 & .000 \\
\hline & April2019 & 3.18 & -4.753 & .000 \\
\hline \multirow{2}{*}{$\begin{array}{l}\text { Technologies are a useful tool in my travels } \\
\text { to rural places (T1) }\end{array}$} & Nov2016 & 3.72 & -.083 & .934 \\
\hline & April2019 & 3.75 & -.083 & .934 \\
\hline
\end{tabular}

The use of technological devices is another critical perspective on the vision of ICTs in rural destinations. Very few tourists give up carrying devices on their rural tourist trips, just $2.6 \%$ of the total. The smartphone is widely used, i.e., close to $90 \%$ of the tourists. Other devices, such as PC books and tablets, have impressive average figures (between 25 and 30\%). However, the latter showed a significant reduction in their use for the second phase of 2019, while wearables increased their use by rural tourists (see Table 7).

There was just a relationship between the use of smartphones and other more developed devices, such as wearables, and the interest of rural tourists for innovative destinations in technology (T4). A t-test has verified this relationship (see Table 8). 
Table 7: Use devices and $t$-Test of Study Period.

\begin{tabular}{|c|c|c|c|}
\hline & \multicolumn{2}{|c|}{ NO } & YES \\
\hline I use any technological device when I travel & \multicolumn{2}{|c|}{2.6} & 97.4 \\
\hline Use Smartphone & \multicolumn{2}{|c|}{10.6} & 89.4 \\
\hline Use PC & \multicolumn{2}{|c|}{70.9} & 29.1 \\
\hline Use Tablet & \multicolumn{2}{|c|}{75.3} & 24.7 \\
\hline Use Others & \multicolumn{2}{|c|}{90.3} & 9.7 \\
\hline Use Wearables (Smart watch. Google Glasses...) & \multicolumn{2}{|c|}{91.6} & 8.4 \\
\hline Use a conventional mobile phone & \multicolumn{2}{|c|}{93.0} & 7.0 \\
\hline Phase & Phase1 & Phase2 & Chi-Sig. \\
\hline I use any technological device when I travel & $=$ & $=$ & ns \\
\hline Use Smartphone & $=$ & $=$ & ns \\
\hline Use PC & + & - & .004 \\
\hline Use Tablet & + & - & .003 \\
\hline Use Other & $=$ & $=$ & ns \\
\hline Use Wearables (Smart watch. Google Glasses...) & - & + & .008 \\
\hline Use a conventional mobile phone & $=$ & $=$ & ns \\
\hline
\end{tabular}

Table 8: Use devices and $t$-Test of T4.

\begin{tabular}{lccc}
$\begin{array}{l}\text { I appreciate that rural destiny tries to } \\
\text { innovate and use technologies to improve } \\
\text { my experience as a rural tourist }\end{array}$ & No & Yes & t-Sig. \\
Use a conventional mobile phone & 3.60 & 3.25 & $\mathrm{~ns}$ \\
Use Others & 3.53 & 4 & .011 \\
Use PC & 3.70 & 3.27 & .000 \\
Use Smartphone & 3.04 & 3.64 & .001 \\
Use Tablet & 3.64 & 3.36 & .026 \\
Use Wearables (Smart watch. Google Glasses...) & 3.52 & 4.11 & .003 \\
\hline
\end{tabular}

\subsection{Types of ICTs used in Rural Tourism}

The study of the utilities of ICTs for rural tourists was a central issue for this work. A part of the model assumed the existence of more relevant technological utilities for RT.

Five of the utilities (U1, U5, U7, U9, and U3) had positive values, between 3.36 and 3.78 points out of 5. Another five (U10, U6, U2, U11, and U8) had negative values, between 1.60 and 2.98 points. The U4 utility ("Seek General Information about Destination") was located just as the average (see Table 9).

However, the comparative results between the two phases (2016 versus 2019) were more relevant. Firstly, due to the majority of profits that had lower values in their earnings in 2016 than in 2019. Second, owing to the increasing value that was higher in many cases: U3 could double its value; U1, U5, and U7 had increment values higher than one point, reaching the level of 4 over 5; in addition, U10 and U9 had higher values; while U4 significantly reduced interest for rural tourists. The $t$-Test could provide statistical validity to all the results cited.

A Principal Component Factor Analysis (PCFA) allows you to summarize the information of the 11 utilities in a few main constructs. Table 10 contains the results of the PCFA. The KMO and Bartlett tests were favorable. It could generate four constructs with an explanatory capacity greater than $76 \%$ of the variance. The composition of the constructs can be interpreted in the following terms: 
Table 9: Use ICTs and $t$-Test of Study Period.

\begin{tabular}{lccccc} 
& \multicolumn{3}{c}{ Mean } & & t-Test \\
\cline { 2 - 3 } \cline { 5 - 5 } & Total Study & Phase1 & Phase2 & & Sig. \\
Destination Apps (U1) & 3.76 & 3.12 & 4.32 & & .000 \\
Consult Maps/GPS (U5) & 3.48 & 2.96 & 4.12 & & .000 \\
To Use Guides (Audio. Video...) (U7) & 3.52 & 1.90 & 4.04 & & .000 \\
Photo/ Videos (U9) & 3.68 & 3.44 & 3.88 & & .050 \\
To Family/Friends Communication (U3) & 3.36 & 1.90 & 3.84 & .000 \\
Reserve Activities (U10) & 2.84 & 2.32 & 3.16 & & .000 \\
Seek Opinions about Tourist Services (U6) & 2.96 & 3.16 & 2.76 & & Ns \\
Seek Resources Opinions (U2) & 2.76 & 2.92 & 2.60 & & Ns \\
Seek General Information about Destination (U4) & 3.00 & 3.60 & 2.48 & & .008 \\
Share SSNN (U11) & 2.24 & 2.28 & 2.24 & & Ns \\
Pay (via smartphone) (U8) & 1.60 & 1.40 & 1.78 & Ns \\
\hline
\end{tabular}

- $\quad$ C1 [U7; U5; U1; U10]: Tourism assistance technologies.

- C2 [U3; U9; U8]: Specific uses of the smartphone.

- C3 [U4; U6; U2]: Information searches.

- C4 [U11]: Use in Social Networks.

The estimation of the values of each construct for each phase (see Table 11) allowed us to observe significant increases for C1, C2, and C3 in 2019, but not for the C4 (SSNN Use) construct. The three-dimensional representation of the values (see Figure 2) presented a positive displacement in 2019, of higher value for the C2 (Specific uses of the smartphone) construct.

Table 10: Factorial Analysis of Using ICTs (Ui).

\begin{tabular}{|c|c|c|c|c|c|}
\hline \multicolumn{6}{|c|}{ KMO and Bartlett test } \\
\hline \multicolumn{4}{|c|}{ Kaiser-Meyer-Olkin measurement of sampling adequacy } & \multicolumn{2}{|c|}{.835} \\
\hline Bartlett's sphericity test & \multicolumn{2}{|c|}{ Approx. Chi-square } & & & \\
\hline \multirow{2}{*}{ components } & \multicolumn{5}{|c|}{ Squared load extraction sum } \\
\hline & eigenvalue & \multicolumn{2}{|c|}{$\%$ variance } & \multicolumn{2}{|c|}{$\%$ accumulated } \\
\hline 1 & 3.937 & \multicolumn{2}{|c|}{35.786} & \multicolumn{2}{|c|}{35.786} \\
\hline 2 & 1.956 & \multicolumn{2}{|c|}{17.781} & \multicolumn{2}{|c|}{53.567} \\
\hline 3 & 1.358 & \multicolumn{2}{|c|}{13.342} & \multicolumn{2}{|c|}{66.909} \\
\hline 4 & 1.068 & \multicolumn{2}{|c|}{9.709} & \multicolumn{2}{|c|}{76.618} \\
\hline \multicolumn{6}{|c|}{ Structure Matrix } \\
\hline & & \multicolumn{4}{|c|}{ component } \\
\hline & & 1 & 2 & 3 & 4 \\
\hline To Use Guides (Audio. Vic & (U7) & .918 & .249 & -.307 & -.039 \\
\hline Consult Maps/GPS (U5) & & .868 & .248 & -.245 & -.018 \\
\hline Destination Apps (U1) & & .857 & .245 & -.217 & .067 \\
\hline Reserve Activities (U10) & & .828 & -.207 & .319 & -.131 \\
\hline To Family/Friends Comm & ion (U3) & -.005 & .902 & -.026 & .114 \\
\hline Photo/ Videos (U9) & & .127 & .833 & -.332 & .125 \\
\hline Pay (via smartphone) (U8 & & .193 & .751 & -.227 & -.251 \\
\hline Seek General Informatior & t Destination (U4) & .103 & .162 & .912 & -.168 \\
\hline Seek Opinions about Tou & rvices (U6) & .095 & .065 & .878 & -.058 \\
\hline Seek Resources Opinions & & .219 & .094 & .757 & -.247 \\
\hline Share SSNN (U11) & & .092 & .276 & .190 & .867 \\
\hline
\end{tabular}


Table 11: Factorial Components and $t$-Test of Study Period.

\begin{tabular}{lcccc} 
& Phase & Mean & $\begin{array}{c}\boldsymbol{t} \text { - Sig. } \\
\text { (unilateral) }\end{array}$ & $\boldsymbol{t}$ - Sig. (bilateral) \\
FACTORIAL C1 & Oct2016 & 3.2066 & .04995 & .001 \\
& May2019 & 3.4371 & .04579 & .000 \\
FACTORIAL C2 & Oct2016 & 2.7139 & .03269 & .00 \\
& May2019 & 2.8970 & .03078 & .000 \\
FACTORIAL C3 & Oct2016 & 2.6890 & .02437 & .864 \\
& May2019 & 3.0869 & .02548 & \\
\hline
\end{tabular}

The relevant issue for the study was related to the relationship between such technological utilities and the variable T4 ("I appreciate that rural destiny tries to innovate and use technologies to improve my experience as a rural tourist"). A Linear Regression Analysis (see Table 12), in which T4 was the dependent variable, and the constructs were the independent variables, allowed the question to be better studied. Constructs C1 (Tourism assistance technologies) and C3 (Information searches) appeared as significant variables; the first one had a very high beta coefficient value (.0914 versus .069). Meanwhile, neither the C3 nor the C4 construct could fit the final model.

Finally, the interest in ICTs (variable T4) presented a satisfying relationship with the candid practice of sharing in the tourist trip. Certainly, there are no significant differences for the moments before and after the trip, however, there is a significant interest in sharing their experiences in the SSNN during the rural tourism trip itself (see Table 13).

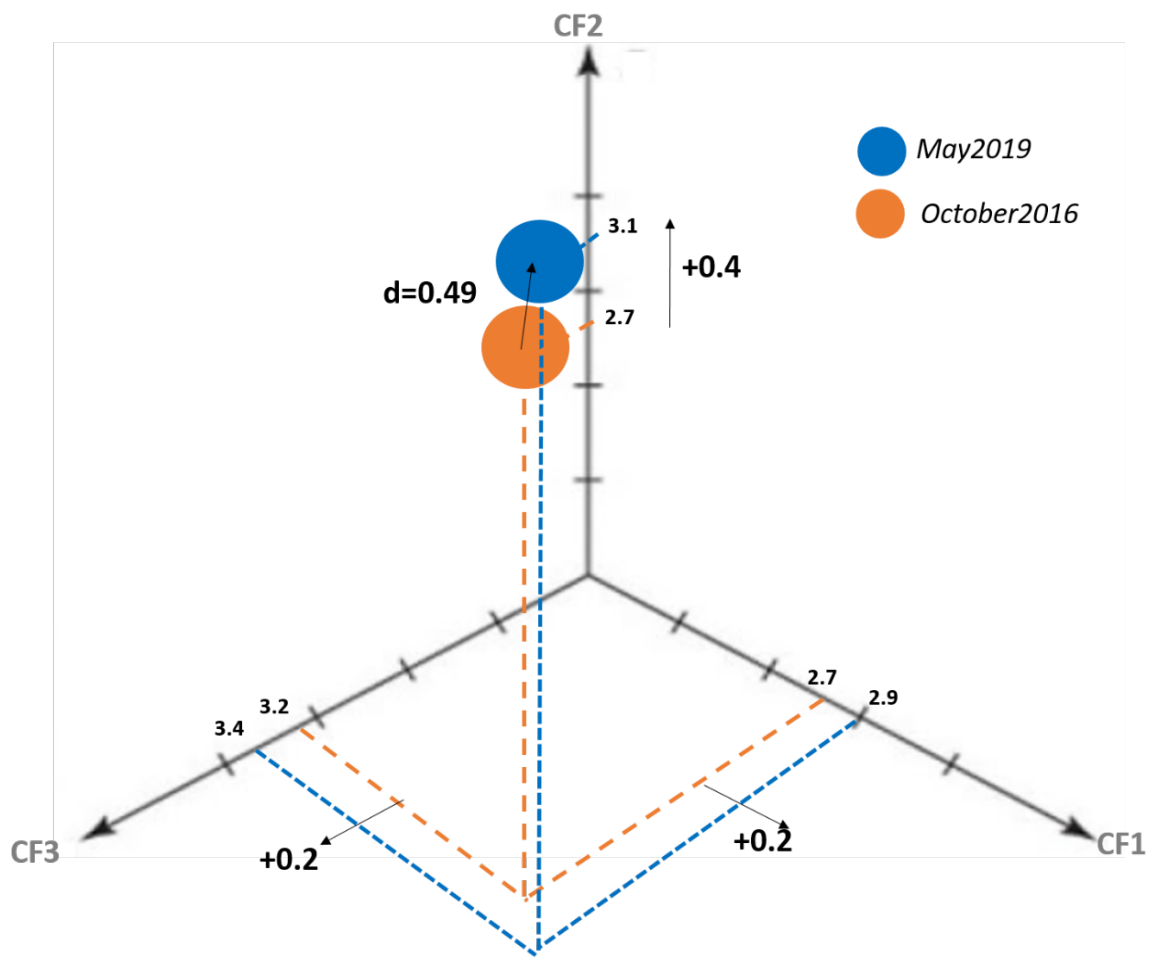

Figure 2: Coarse-Time Positioning with respect to Factorial Components 1-2-3. 
Table 12: Results of Linear Regression.

\begin{tabular}{ccccc} 
Model & $\mathbf{R}$ & R square & R square ajusted \\
\hline 1 & .931 & .866 & .865 \\
2 & .933 & .870 & .869 \\
& \multirow{2}{*}{ Model } & & $\begin{array}{c}\text { Standarized } \\
\text { coefficients }\end{array}$ & Sig. \\
\cline { 3 - 4 } & & Beta & .008 \\
\cline { 3 - 4 } 2 & (Constant) & & .000 \\
& Construct C1 & .931 & .000 \\
& (Constant) & & .000 \\
& Construct C1 & .914 & .006 \\
\hline
\end{tabular}

Table 13: t-Test of T4 / Travel Moment Share.

\begin{tabular}{lccc}
\multicolumn{5}{c}{ I appreciate that rural destiny tries to innovate and use technologies to improve my } \\
experience as a rural tourist
\end{tabular}

\section{RESULTS DISCUSSION}

The usefulness of ICTs was high in rural tourists. The values attributed as a tool and as a fundamental part of the trip were the highest ones (approx. 3.7 / 5). The role of ICTs as a factor in improving the tourist experience was also essential (3.5 / 5). However, the most crucial meeting of the paper has been focused on verifying a temporary growth in all the useful attributes of ICTs, especially in terms of being a fundamental element and improving the tourist experience (values of 4.06 / 5 for the second phase 2019). One the other hand, the value (appreciate) given to smart destinations could grow by more than one point (from 2.97 to 3.97 / 5).

The use of smartphones was high in rural tourism trips, with a percentage of up to $90 \%$ of tourists. It is appearing, also, a significant increase in the use of wearables in the second phase of 2019.

The most exciting results were related to technological utilities for rural tourism. Three utilities stood out for the entire phase of the study: Destinations Apps; Taking photos/videos; and Guides (audio/video). In addition, there were evident changes in the time, i.e., 2019 was highlighted with higher values regarding Consult Maps (4.1 / 5) and Use Guides (4/5). The changes in the utilities were interesting, however, they were the highest valuation of the rural tourists and the more significant number of ICTs to be considered.

The C1 (Tourism assistance technologies) construct that integrated utilities, Guides + Maps + Destination App + Reserves during the trip, were the most important, in the context of ICTs in rural tourism. The accumulated variance (35.7 out of a total of 76.6\%) was high, as well as the beta coefficient in the line regression (0.931). 
There was abundant evidence on the use of social networks before and after a tourist trip (the prosumer concept). This paper could explore an essential use of sharing ICTs over trip, with a significant increase in2019 (75.4\% versus $52.8 \%)$.

Consequently, the hypotheses must be rejected (Table 14).

Table 14: Hypothesis contrast.

\begin{tabular}{|c|c|c|}
\hline \multicolumn{2}{|r|}{ HYPOTHESIS } & DECISION \\
\hline H1 & ICTs low interest to the & Rejected \\
\hline & rural tourist & $\begin{array}{l}\text { The interest in technological utilities grows high in rural tourists } \\
\text { in } 2019 \text {. }\end{array}$ \\
\hline \multirow[t]{3}{*}{ H2 } & Information ICTs before & Rejected \\
\hline & the rural trip & $\begin{array}{l}\text { The most valued technological utilities correspond to the } \\
\text { assistance provided to tourists at the destination itself. }\end{array}$ \\
\hline & & $\begin{array}{l}\text { There has also been more significant use of social networks } \\
\text { during the rural tourism trip. }\end{array}$ \\
\hline
\end{tabular}

\section{CONCLUSSIONS AND PRACTICAL IMPLICATIONS}

Smart tourism is an unstoppable concept, not only for the contributions it makes to public institutions and tourism service companies, but also for the permanent implementation of ICTs in the daily use and habits of individuals, and therefore, of tourists.

The application of smart tourism in areas other than urban areas is very complex (Gretzel, 2018). It is essential to avoid the direct export of the operating principles of smart tourist destinations to all tourist areas. Therefore, the smart specialization (Weindenfeld, 2018) approach is exciting to guide development in heritage tourism (Garau, 2015) and rural tourism (Sedmak et al., 2016).

The Smart Region and Smart Rural Village formulas are still at the beginning of their designs. In addition, they are being developed for very different topics, for the sake of specialization. However, they can be accepted as concepts to promote the study and development of smart rural tourism (Zavratnik et al., 2018).

Studying the meeting point regarding the technological design of the rural destination is crucial. It is represented by an associating of the utilities of the ICTs developed by the tourism service institutions and companies, with the daily (general) and specific needs (at the tourist time) of the demand to give value to the experience of tourist co-creation based on the ICTs (Ballina, 2019).

The rural destination should consider that the smartphone is an instrument that tourists use intensely to enjoy. In a broad way, it is the tourist experience of nature and rurality (Cooper, 2016). The smartphone is a permanent gateway to all the information they need to get the most out of such experience during the tourist trip. The "during" in question is critical. Smart applications that assist tourists in the rural environment are of crucial importance.

In this context, an App of the well-designed rural destination, and complete in its utilities (information, maps, resource guides, on-time reservations) should be the first approach to the smart rural destination.

All agents interested in rural tourism, from public administration to researchers, logically through tourism application developers and rural tourism entrepreneurs, must abandon the maximalist orientation of the STD. However, we must look for the specificities of each rural area, and its specific tourist experiences must add a more significant smart component. 
The limitations of this study were related to traditional concepts in the surveys used. Respondent biases are always difficult to control. Also, the need to work with the same questionnaire has prevented us from adding our existing ICT utilities such as Chatbots, beacons, Internet of Things (IoT), just existing in 2016. To improve future results, within this same line of research, we are working with a rural Hiking Apps company, to obtain direct and objective data on its use by rural tourists.

\section{BIBLIOGRAPHY}

Ballina, F. J. (2019). Smart tourism destination, phygital experience, and rural tourism. International Journal of Information Systems and Tourism, 4(1), 41-52.

Barbu, I. (2013). The factors appearance and development of rural tourism. Annals of the University of Oradea. Economic Science Series, 22, 750-758.

Benckendorff, P., Sheldon, P. J., \& Fesenmaier, D. R. (2014). Tourism information technology (2nd ed.), Wallingford, UK: CABI.

Bethapudi, A. (2015). Role of ICT in promoting a rural tourism product. Journal of Tourism \& Hospitality, 4(3), http://dx.doi.org/10.4172/2167-0269.1000154

Boschma, R. (2014). Constructing regional advantage and smart specialization: comparison of two European policy concepts. Science Regional, 13(1), 51-68.

Celdrán-Bernabeu, M. A., Mazón, J. N., Ivars-Baidal, J. A., \& Vera-Rebollo, J. F. (2018). Smart tourism. A study on systematic mapping. Cuadernos de Turismo, (41), 655-658.

Cooper, D. I. A. (2016). The impact of generational change on future demand for tourism experiences. In M. Scerri \& L. K. Hui (Editor). CAUTHE 2016: The Changing Landscape of Tourism and Hospitality: The Impact of Emerging Markets and Emerging Destinations (pp. 278-292). Sydney: Blue Mountains International Hotel Management School. Retrieved in 2020, March 02, from http://search.informit.com.au/documentSummary;dn=9002188703 47486;res=IELBUS

Cunha, C. R., Morais, E. P., \& Martins, C. (2018) Can we use big data analytics to leverage tourism in rural tourism destinations? In 32nd International Business Information Management Association Conference - IBIMA 2018. (pp. 145-156). Seville.

Dolnicar, S. (2002). Review of data-driven market segmentation in tourism. Journal of Trave/ \& Tourism Marketing, 12(1), 1-22. http://dx.doi.org/10.1300/J073v12n01_01

Femenia, F., Perles, J. F., \& Ivars, J. A. (2018). Smart destinations and tech-savvy millennial tourists: hype versus reality. Tourism Review, 74(1), 63-81. http://dx.doi.org/10.1108/TR-02-2018-0018

Garau, C. (2015). Perspectives on cultural and sustainable rural tourism in a smart region: The case study of Marmilla in Sardinia (Italy). Sustainability, 7, 6412-6434. http://dx.doi. org/10.3390/su7066412

Gretzel, U. (2018). From Smart de3stinations to Smart tourism regions. Investigaciones RegionalesJournal of Regional Research, 42, 171-184.

Gretzel, U., Ham, J., \& Koo, C. (2018). Creating the city destination of the future: The case of smart Seoul. In Y. Wang, A. Shakeela, A. Kwek, C. Khoo-Lattimore. Managing Asian Destinations (pp. 199-214). Singapore: Springer. https://doi.org/10.1007/978-981-10-8426-3_12

Hays, S., Page, S. J., \& Buhalis, D. (2012). Social media as a destination marketing tool: its use by national tourism organisations. Current Issues in Tourism, 16(3), 211-239. http://dx.doi. org/10.1080/13683500.2012.662215. 
Ivars, J. A., Celdrán, M. A., Mazón, J. N., \& Perles, Á. F. (2017). Smart destinations and the evolution of ICTs: A new scenario for destination management? Current Issues in Tourism, 22(13), 1581-1600. http://dx.doi.org/10.1080/13683500.2017.1388771

Ivars-Baidal, J., \& Rebollo, J. F. V. (2019). Planificación turística en España. De los paradigmas tradicionales a los nuevos enfoques: planificación turística inteligente. Boletín de la Asociación de Geógrafos Españoles, 82(2765), 1-31.

Jovicic, J. (2017). From the traditional understanding of tourism destination to the smart tourism destination. Current Issues in Tourism, 22(3), 276-282. http://dx.doi.org/10.1080/136835 00.2017 .1313203

Koo, C., Shin, S., Gretzel, U., Hunter, W. C., \& Chung, N. (2016). Conceptualization of smart tourism destination competitiveness. Asia Pacific Journal of Information Systems, 26(4), 367-384.

Luque Gil, A. M., Zayas Fernández, B., \& Caro Herrero, J. L. (2015). Los destinos turísticos inteligentes en el marco de la inteligencia territorial: conflictos y oportunidades. Investigaciones Turísticas, 10, 1-25. http://dx.doi.org/10.14198/INTURI2015.10.01.

McCann, P., \& Ortega, R. (2013). Smart specialization, regional growth, and applications to European Union cohesion policy. Regional Studies, 49(8), 1-26.

Mora, L., Bolici, R., \& Deakin, M. (2017). The first two decades of smart-city research: A bibliometric analysis. Journal of Urban Technology, 24(1), 3-27. https://doi.org/10.1080/10630732.201 7.1285123

Moscardo, G., \& Murphy, L. (2014). There is no such thing as sustainable tourism: re-conceptualizing tourism as a tool for sustainability. Sustainability, 6(5), 2538-2561. http://dx.doi.org/10.3390/ su6052538

Nkosana, T., Skinner, J., \& Goodier, C. (2016). Challenges of ICT adoption and utilization in small rural restaurants: a case study of the KwaZulu-Natal Midlands. African Journal of Hospitality, Tourism and Leisure, 5(4), 1-11.

Perles-Ribes, J. F., Ramón-Rodríguez, A., Vera-Rebollo, J. F., \& Ivars-Baidal, J. (2017). The end of growth in residential tourism destinations: steady-state or sustainable development? The case of Calpe. Current Issues in Tourism, 21(12), 1-31. https://doi.org/10.1080/13683500. 2016.1276522

Rodrigues, A., \& Ventura, A. (2019). A smart rural project for tourism of Madeira Island. IOP Conference Series: Materials Science and Engineering, 471(9), 1-10. https://doi. org/10.1088/1757-899X/471/9/092042.

Saarinen, J., Rogerson, C. M., \& Hall, C. M. (2017). Geographies of tourism development and planning. Tourism Geographies, 19(3), 307-317. https://doi.org/10.1080/14616688.2017.1 307442

Santos, M. C., Veiga, C., \& Águas, P. (2016). Tourism services: facing the challenge of new tourist profiles. Worldwide Hospitality and Tourism Themes, 8(6), 654-669. http://dx.doi. org/10.1108/WHATT-09-2016-0048

Sedmak, G., Planinc, T., Kociper, T., \& Planinc, S. (2016). Manager's perceptions of the role of ICT in rural tourism firm's efficiency: The case of Slovenia. Tourism (Zagreb), 64(3), 339-345.

Shen, S., \& Wang, Q. (2018). Innovation Strategy of traditional village tourism development in Liaoning Province under the background of Smart Village Construction. In International Conference on Intelligent Transportation, Big Data \& Smart City (pp. 85-88). Vientiane, Laos: IEEE. http://dx.doi.org/10.1109/ICITBS.2018.00030 
Upkabi, D. C., \& Karjaluoto, H. (2017). Consumers' acceptance of information and communications technology in tourism: A review. Telematics and Informatics, 34(5), 618-644. https://doi. org/10.1016/j.tele.2016.12.002

Valdés, L., \& Del Valle, E. (2003). El turismo rural en Asturias: un desarrollo modélico. In Ministerio de Agricultura, Pesca y Alimentación. Libro Blanco de la Agriculturay el Desarrollo Rural (pp. 259-264). Madrid: Ministerio de Agricultura, Pesca y Alimentación.

Weindenfeld, A. (2018). Tourism diversification and its implications for smart specialization. Sustainability, 10, 319. http://dx.doi.org/10.3390/su10020319

Weinstein, A. (2011). Segmenting technology markets: applying the nested approach. Marketing Intelligence \& Planning, 29(7), 672-686. https://doi.org/10.1108/02634501111178695

Wilson, S., Fesenmaier, D. R., Fesenmaier, J., \& Van Es, J. C. (2001). Factors for success in rural tourism development. Journal of Travel Research, 40, 132-138.

Yan, Y. (2018). Market research and analysis of Smart rural travel in Nanjing on the mobile terminal. In International Conference on Humanities and Advanced Education Technology (pp. 15-18.). Guangzhou, China.

Yigitcanlar, T., Kamruzzaman, M., Buys, L., Ioppolo, G., Sabatini-Marques, J., da Costa, E. M., \& Yun, J. J. (2018). Understanding "smart cities": Intertwining development drivers with desired outcomes in a multidimensional framework. Cities (London, England)

Zavratnik, V., Kos, A., \& Duh, E. S. (2018). Smart Villages: Comprehensive review of initiatives and practices. Sustainability, 10, 2559. http://dx.doi.org/10.3390/su10072559

Zdorov, A. B. (2004). Tourism Economics (272 p.). Moscow: The Finance and Statistics. 